\title{
Getting to Know Herbert Hoover, Enigmatic Humanitarian
}

\author{
Peter I. Rose
}

Published online: 8 September 2010

(C) Springer Science+Business Media, LLC 2010

In the early 1980s, I came to know an elderly Russian Jew named Simon Schargo. The father of my colleague, Professor Nelly Schargo Hoyt, we met at a Christmas party when he was visiting his daughter far from his home in Geneva, Switzerland. As we sat in Nelly's living room in Northampton, Massachusetts, I asked Mr. Schargo what he did, implying, I guess, that I assumed he was retired. He responded with an almost indignant, "No, what do I do?"

I apologized and asked, "What do you do?" He said, "I am with the American Jewish Joint Distribution Committee. I'm sure you've never heard of it?"

\section{Serendipitous Encounters}

I explained to Mr. Schargo that, not only did I know the agency but that my Dutch wife, Hedy, a war orphan who had quite literally lived the life of Anne Frank, had been brought to America through the efforts of "The Joint." It also happened to be one of a number of organizations that I, a sociologist conducting research on the making and implementing of American refugee policy, was studying. Amazed by the personal connection and interested in my research, it was the beginning of a friendship that lasted to the end of his long life.

Through our serendipitous encounter, Simon Schargo soon became a critical source of information about the early days of organized efforts to aid the dispossessed. What I could not imagine at the time was that there would be more surprises to come. What I learned about his agency helped

\section{P. I. Rose $(\bowtie)$}

96 Round Hill Road,

Northampton, MA 01060, USA

e-mail: prosewriter@me.com to fill in a number of blanks in my research the history of his agency and the efforts of the AJJDC in the 1930s and 1940 s and in more recent years. What I learned about him was even more intriguing.

Simon was born in Nikolaev, Ukraine, the grandson of the shamas (sexton) of a large synagogue in Odessa, and son of a Socialist Revolutionary who opposed the Bolsheviks and was eventually forced to flee the country in 1920. Simon, who soon followed, beginning an odyssey of his own that would take him to Berlin, then Paris, then Lisbon, and then Geneva, had been trained as an agronomist and started his early career working on the planned farming activities of the Baron de Hirsch Foundation that was underwriting the efforts to assist Russian Jews in improving their terrible lot without having to resort to emigration. One of the major parts of the scheme was to develop agricultural communes in the Crimea. In the course of this he had gotten to know a number of officials in the new Soviet government and other key players and planners in the area. When the devastating famine struck in 1919, he told me, he broadened the scope of his assistance and was seconded to serve as an advisor to a mission organized by Herbert Hoover that entered the country a year later.

A bit astounded as he related this, I stopped him and said something like, "You did what? With whom?"

"I worked for Hoover's relief efforts."

Now I felt like Alice in Wonderland, for things were getting "curiouser and curiouser."

I had just spent five years conducting research, doing fieldwork in South East Asia, in Geneva, and throughout the U.S., and writing about the rescue, relief, and resettlement of those who fled from Indochina after the fall of Saigon in 1975. In the course of my study, I had become ever more interested in the people who worked with refugees during that period 
and in the 1930s and 1940s. Some of the research was conducted in the extensive archives of the Hoover Institution for War, Peace and Revolution at Stanford University which houses the files of the International Rescue Committee and some of the other agencies engaged in refuguee work, but, truth to tell, I never thought much about the man for whom the institution is named.

Then one day, back at my home in Northampton, I came upon a number of misplaced tapes of interviews with Simon Schargo I had made a decade earlier. Hearing them again suddenly prompted me to go back even further in time, back to the earliest days of organized humanitarian relief efforts. Wherever I looked for information, that same name stood out: Herbert Hoover. Soon after I returned to Stanford and began to dig into the matter. I quickly learned that, during and immediately after World War I, Hoover was indeed involved in setting up and administering a series of enterprises that brought care and succor to millions of people caught up in the turbulence of war in Europe and the devastating effects of natural disasters in Soviet Russia and many other countries shortly thereafter.

Simon Schargo's revelation had a secondary effect, especially on one who had long taught about the nature of prejudice and the danger of saying "My mind is made up, don't confuse me with the facts."

Like many Americans born in the early 1930s and raised by parents who were ardent supporters of FDR, I grew up with a very narrow and quite negative image of Herbert Hoover, "the hard-hearted, failed president." The discovery of Hoover's good works served as an impetus to look more closely at the man and his accomplishments as well as his failures, and to try to unravel the enigma. Once into the project, I found that much already had been written about both.

For example, in his seminal book, The Great Depression 1929-1940 (1984), historian Robert S. McElvaine noted that, "The public memory of many of our presidents is clouded by myth...No past president has suffered quite as much abuse as Herbert Hoover. He is used as an example of a poor leader, a weak president, and an awful politician." In his chapter titled "In the Right Place at the Wrong Time," McElvaine sought to explain the puzzling character of former president and the basis of the vilification he endured. He described Hoover's widely praised actions in Europe and his widely perceived failures to aid his own people during the depths of the Depression. Many Americans complained that, "He would feed the foreigners but not his own people." Close examination of the record indicates that, indeed, there is more than a kernel of truth in the portrayal.

Many older scholars cited by McElvaine and, more recently, by Daniel Alef in his book, From Angel to Demon (2008), and many others have tried to explain the seeming contradictions in Hoover's reactions and subsequent actions in response to foreign and domestic crises, especially the latter. Many speculate on what happened to a man who, in his early years, appeared to embody all of those virtues that would form the creed of the Boy Scouts of America, founded in 1912, when Hoover was already a truly selfmade man and seen as a model citizen. There is ample evidence that he was "trustworthy, loyal, helpful, friendly, courteous, kind, thrifty, brave, clean and reverent." Perhaps it was because he possessed all these estimable traits and was also widely recognized as a both a conscientious manager and a driven go-getter-not unlike his hero, Theodore Roosevelt, he would be held up as the embodiment of a compassionate conservative and pragmatic progressive before such expressions ever entered the vernacular - and before critics began to write about his colossal ego and his colossal failures.

\section{American Idol}

Herbert Hoover was born in West Branch, Iowa, on August 10, 1974. He was the son of a blacksmith of German descent and a Canadian-born, Scots-Irish mother, both of whom were hardworking Quakers who imbued the boy they called "Bert" with a set of values that emphasized thrift, sobriety, personal privacy and social responsibility. By 1884 , both parents had died. Young Herbert stayed for a time with nearby relatives before being sent to Newberg, Oregon to live with his uncle. John Minthorn.

For several years Hoover attended the Friends Pacific Academy while working in his uncle's real estate office in the capital city of Salem. In 1891 he entered the first class of the newly established Leland Stanford Junior University in Palo Alto. He studied a variety of subjects, engaged in both sporting and social activities, and became an active spokesman for those on scholarships, like himself. He graduated in 1895 with a degree in geology.

Soon after his graduation from Stanford he moved from Palo Alto to Nevada City, California, to work as both prospector and apprentice engineer. From all reports, he showed remarkable talent for administration in the rough and rugged mining industry. Three years later he joined the British firm, Bewick Moreing, and was sent to Australia. It would be the first of a number of overseas jobs he had in the early days of a three-phase career, engaging in challenging experiences that in a few short years would turn him into a world - and worldly - traveler, innovative technician, skillful administrator, and very wealthy man.

In 1898 his company transferred him to China where he became engaged in more civil than mining engineering, planning and building coal mining and port facilities. Within a year he was caught up in the turbulence of the anti-western campaign to become known as the Boxer Rebellion, a movement that sought to rid the Middle Kingdom of its 
"foreign devils," not least the likes of Herbert Hoover and other Christian outsiders and what they represented.

Caught up in the turmoil, Hoover and his young bride, Lou Henry, a Stanford classmate and fellow geologist, sought sanctuary in the coastal city of Tsiensin where he is reported to have risked his own life to save and protect many fellow "westerners" as well as a number of Chinese children under siege. This would prove to be a portent for much larger efforts thousands of miles and a decade away.

From China Hoover moved on, accepting assignments by his firm in many different countries, including those in various parts of South America and South Africa. Eventually the Hoovers settled down near the home office in London. In 1908 he left the employ of Bewick Moreing and started his own mining company. The business flourished, as did the Hoovers' network of friends and business contacts. In the early summer of 1914, Archduke Franz Ferdinand of Austria was assassinated on a Sarajevo streetcorner. Many historians would later claim that that singular event triggered a chain reaction leading to one of the bloodiest wars of all times. As turmoil and panic spread across the continent, many U.S. citizens living there feared being trapped and then caught in the crossfire of a conflict. Almost immediately Hoover and his wife became involved in a campaign to find assistance and transport to move the expatriates to safety in the United Kingdom.

Their efforts sought to provide aid that included the distribution of food and clothing, steamship tickets, and cash to thousands of American businessmen, students, and tourists. It was carried out with little fanfare with the assistance of hundreds of volunteers, some of whom were American Rhodes Scholars studying in England who had been recruited by Hoover. Commenting on these activities, the future president is reported to have said, "I did not realize it at the moment, but on August 3, 1914, my career was over forever. I was on the slippery road of public life." It was clearly a watershed.

Recognizing his organizational, managerial and diplomatic talents, and his apparent genuine sympathy for those in distress, the American ambassador to the United Kingdom, Walter Hines Page, asked Herbert Hoover to organize a campaign to provide relief for the suffering peoples of Belgium and northern France. The Committee for Relief in Belgium (CRB) was born.

\section{Engaged Humanitarian}

In many ways the CRB was to become a model for the institutionalization of humanitarian activities, the professionalization of voluntarism, and a prototype of a host of organizations designed to serve the needs of the victims of both man-made and natural disasters. Hoover's almost single-handed organization of the relief effort and his appeal for funds (thirty percent of them given by private donors, the rest from government) to save the people from starvation were both highly successful. He managed to negotiate with both sides in a clash in which the United States government would not get directly involved for another three years. His agency is said to have saved seven million Belgians and at least two million French people from starvation.

The Democratic President, Woodrow Wilson, endorsed Hoover's work with the CRB. When the United States did enter the war, Wilson appointed him head of a new body, established under the president's authority Executive Order 2679-A, the U.S. Food Administration. The USFA's mandate was "to assure the supply, distribution, and conservation of food during the war; facilitate transportation of food and prevent monopolies and hoarding; and maintain governmental power over foods by using voluntary agreements and a licensing system."

Hoover told President Wilson he would accept the job as long as two caveats were met: first, that he receive no pay to avoid any thought that this was a move for selfaggrandizement; second, that he maintain full control over the agency. The president accepted Hoover's terms. With the latitude given him, Hoover quickly became the "Food Czar of America." The appointment seemed to suit his idiosyncratic mien and his proclivity for assertive dominance and paternalistic altruism.

Like the proverbial little girl with the little curl, if seems that when he was good, he was very, very good, but when he was bad he was awful. The latter was not to be evident for another decade.

In his powerful position at the Food Administration, Hoover urged his fellow Americans to sacrifice for the cause and used the power of his office to coerce many, especially farmers, to meet his tough demands. "FOOD IS AMMUNITION, DON'T WASTE IT," said the posters prepared by a special advertising campaign. He asked people to "...go back to simple food, simple clothes, simple pleasures, Pray hard, work hard, sleep hard, and play hard. Do it all courageously and cheerfully." Like the CRB, Hoover's efforts with the Food Administration were clearly sterling achievements.

Once the war was over, Hoover became engaged in another public-private venture, helping to organize and then to head the American Relief Administration (ARA). In many ways like the $\mathrm{CRB}$, it, too, was a harbinger of actions and activities yet to come, not least the establishment of the United Nations Relief and Rehabilitation Administration in 1943. (That effort was headed by another progressive Republican, former New York State governor, Herbert M. Lehman.) Hoover also pioneered what is today known as USAID and efforts to coordinate cooperation of non-governmental organizations (NGOs) and various agencies of the government. 
According to H.H. Fischer, the ARA administration's official historian, the primary goal of the agency was to provide food relief, but it also engaged in other sorts of work including rehabilitation. Eventually its operations were present in twenty different countries including Soviet Russia.

Initially the new Bolshevik government, suspicious of American intentions, barred proffered services from being set up inside its borders. However, after the horrible famine during the winter of 1920-1921 and, according to Fischer, after the writer Maxim Gorky petitioned Vladimir Lenin to provide relief, the new Soviet government recognized the need for the ARA in Russia. Massive assistance was then given to the Soviet state. The program doubtlessly benefitting from the onthe-ground assistance of local specialists like the Ukrainian agronomist, Simon Schargo.

But as Benjamin M. Weissman, author of Herbert Hoover and Famine Relief in Soviet Russia, 1921-1923 (1974), noted, within a few short years, Hoover and his people were again out of favor and the program ended. Soon after the ARA ceased all of its operations.

In the brief period of its existence the ARA set many precedents, not only offering both immediate aid in the form of food and medicine but also what today would be called "a catalyst for sustainable development" for those in devastated populations, echoes of matters being discussed regarding the plight of Haitians as I write. With the ending of ARA operations, Hoover seemed to be readying himself for what would turn out to be the third phase in his career.

\section{From Paragon to Pariah}

While working overseas it mattered little to Herbert Hoover whether he was serving the victims of man-made disasters or natural ones. His talent for organization seemed to serve him and his causes well. In fact, his achievements won plaudits from those across the political spectrum and many say that, at the time, he was one of the most revered men in the world.

Both Democrats and Republicans looked to Hoover as a potential leader; each party hoped to benefit from his reflected glory. It is credibly reported that a young Assistant Secretary of the Navy, Franklin Delano Roosevelt, thought Hoover would make a fine Democratic Party candidate for president.

Given his close relationship to President Wilson this is not as far-fetched as it now seems. FDR proved to be quite prescient: Hoover was presidential timber, but, ending speculation about his true partisan colors, the engineer declared himself a Republican, albeit a progressive one, again, much in the mold of Teddy Roosevelt. The year was 1920 , and it is said that when he announced his party affiliation he did so already harboring ambitions to the highest office in the land.
During the next eight years he dutifully served as a multitasking Secretary of Commerce under both Warren G. Harding and Calvin Coolidge. Neither man was said to be close to Hoover personally. Both bridled at what they saw as the Secretary's far too liberal policy orientations, but they reveled in having one of the most popular men in the country inside their administrations.

At the Department of Commerce Hoover put to good use his experience running a variety of enterprises, and even favored the selective use of governmental intervention to keep the wheels of progress turning. He was no rigid party hack. In the 1928 run for the presidency, Herbert Hoover won 58 per cent of the popular vote in a classic election that pitted him, a dour and "dry," mid-Western, small-town Protestant Republican, against the flamboyant, "wet," Eastern, urban Catholic Democratic candidate, Al Smith. Given the state of the economy, the mood of the country and the biases expressed by many about the specter of a "papist" in the White House, Hoover's overwhelming victory was almost a foregone conclusion.

What few people know (I didn't) or remember is that prior to his landslide election and in the early days of presidency, the new president was a vigorous advocate for some of the programs that later would become centerpieces of the New Deal itself, not least the sponsorship of the government-funded Reconstruction Finance Corporation, the idea of insurance on bank deposits, and the Securities Act. Only years later would a number of notable Democrats pay grudging homage to Hoover's pioneering ideas.

In other ways he was hardly a proto-New Dealer. Many of his ideas were very different from those in Roosevelt's camp. For one thing he was a Social Darwinist who echoed the sentiments of such writers as the sociologist, William Graham Sumner, who had written about "what social classes owe to each other." The new president rarely addressed the vast array of categorical inequities extant in American society itself or their causes.

While he often spoke of the responsibilities Americans have to their fellow men, and did, as noted, favor some government structures to enhance economic matters, he worried about providing federal support that would increase the dependency of the destitute. He felt that if there had to be aid to those struggling to run that equal race, the burden should be on their communities and private charities and not the government. He held firmly to this position in the face of mounting evidence of the overwhelming impact of the Depression on hardworking Americans who, through no fault of their own, were rapidly being displaced, impoverished and made destitute.

In the rare instances where it did occur, President Hoover's actual governmental outreach was highly discriminatory. In the most celebrated or notorious example- he was willing to use public funds to bail out failing banks but 
not to help the unemployed, lest, he worried, they become reliant on the dole. Despite the worsening of the situation and the growing desperation across the land, Hoover seemed to become more rigid in his thinking, more righteous in his rhetoric, and more defensive in his posturing. Repeatedly, he turned a blind eye to the inhabitants of shantytowns that would be forever known by the negative appellation, "Hoovervilles." Despite his claim that he never approved the attacks by U.S. army forces led by a young Douglas MacArthur against veteran "Bonus Marchers," Hoover's name would also be linked to that action.

Some have said that a hostile Congress sabotaged Hoover; others say that he was a convenient scapegoat for the bank failures that triggered the collapse of the economy, "a disaster just waiting to happen during the unprecedented boom of the 1920s for which he had no responsibility." Still others tend to agree with Robert McElvaine that "Herbert Hoover's greatest virtue may have been his consistency; his worst defect was his rigidity."

As is well known, Hoover went down to ignominious defeat in the election of 1932, viewed by some fellow Republicans and many Democrats as being, if not responsible for the Depression, an ineffective force against its ravages on the economy and the society. Hoover's one-time advocate, the new president, became more than a political opponent but a nemesis. The former president was soon a principal spokesman railing against what he saw as FDR's advocacy of "statism" on a grand scale. That tension was surely a factor when, despite the exigencies of war, the well-known persecutions of Jews and others, and the destructions of nations that beggared even those of World War I, Roosevelt, embittered by the attacks of his predecessor, never turned to the man who, whatever else he was, had done so much to ameliorate the suffering of those in that earlier conflict.

It was not until 1947 that Hoover was brought back to Washington. President Harry Truman asked him to join a committee to assess and reorganize various departments of government. Soon he was elected its chair. Truman's successor, General Eisenhower also asked Hoover to do similar work during his administration.

Hoover died on October 20, 1954.

Outside the Hoover Institution and next to the Stanford's iconic Hoover Tower there is a handsome round memorial, erected by a federal commission in 1974. Around its lip are five adjectives: ENGINEER, STATESMAN, PUBLIC SERVANT, AUTHOR, HUMANITARIAN. It is a tribute to a man once seen as a paragon of American virtue and leadership. Not surprisingly, there is no reference to the pariah he became.

Peter I. Rose a sociologist and writer, is Senior Fellow of the Kahn Institute and Sophia Smith Professor Emeritus at Smith College. A frequent visiting scholar at Stanford University's Hoover Institution, his books include They and We, The Subject is Race, Mainstream and Margins, Working with Refugees, Tempest-Tost, The Dispossessed, and, most recently, With Few Reservatons: Travels at Home and Abroad. 